\title{
Community structure of coral reef zooplankton in Isla del Coco National Park, a natural World Heritage site in the Eastern Tropical Pacific
}

\author{
Octavio Esquivel-Garrote ${ }^{1,2 *}$ \& Álvaro Morales-Ramírez ${ }^{1,3}$ \\ 1. Escuela de Biología, Universidad de Costa Rica, San José, Costa Rica. \\ 2. Laboratório de Zooplâncton, Instituto de Oceanografia, Universidade Federal de Rio Grande, Rio Grande, RS, Brasil; \\ octageo@gmail.com \\ 3. Centro de Investigación en Ciencias del Mar y Limnología, Universidad de Costa Rica, San José, Costa Rica; \\ alvaro.morales@ucr.ac.cr \\ * Correspondence
}

Received 30-I-2019. C Corrected 25-IV-2019. Accepted 04-VII-2019.

\begin{abstract}
Introduction: Zooplankton is a major link between primary producers and the following trophic levels, and in coral reefs they represent an energy source for corals and involve complex assemblies integrating a wide variety of species form different functional groups. Objective: To define interannual changes in zooplankton assemblies in coral reefs of Isla del Coco. Methods: Three coral reefs system were sampled. Two or three samples were taken by surface horizontal trawls in each coral reef from 2009 to 2012, using conical zooplankton nets of 200 and $500 \mu \mathrm{m}$ mesh sizes at different times of the day. Physical and chemical variables were measured before zooplankton sampling. Results: We identified 24 taxonomic groups of macrozooplankton and 22 of mesozooplankton. Copepods were the most abundant taxa $(87.1 \%)$ of the total abundance of mesozooplankton and macrozooplakton (58.9\%); however, chaetognaths $(35.6 \%)$ exceeded copepods $(35.4 \%)$ in abundance in macrozooplankton samples during 2011. Mesozooplankton samples showed higher abundance (68753.2 \pm 9123.2 ind $\left.\mathrm{m}^{-3}\right)$ and biomass $\left(85.14 \pm 11.3 \mathrm{mg} \mathrm{DW} \mathrm{m}^{-3}\right)$ than macrozooplankton samples $\left(4454.9 \pm 751.0 \mathrm{ind}^{-3}\right.$, $22.8 \pm 3.8 \mathrm{mg} \mathrm{DW} \mathrm{m}^{-3}$ ). The interannual macrozooplankton community structure did not change significantly (ANOVA, $p=0.368$ ), but did change for mesozooplankton (ANOVA, $p=0.001$ ). Variations in physical and chemical variables influenced the community structure for both meso and macrozooplankton, increasing or decreasing organism abundance. Conclusions: Coral reef zooplankton of Isla del Coco resembles that of other coral reefs under the influence of oceanic conditions, with a fauna formed mainly by calanoid copepods, chaetognaths and appendicularians, and depending on oceanographic conditions, the abundance of these groups can change.
\end{abstract}

Key words: Isla del Coco; oceanic island; plankton; environmental variables; abundance; diversity, biomass.

Esquivel-Garrote, O., \& Morales-Ramírez, A. (2020). Community structure of coral reef zooplankton in Isla del Coco National Park, a natural World Heritage site in the Eastern Tropical Pacific. Revista de Biología Tropical, 68(Suppl. 1), S248-S260.

Coral reef ecosystems develop and prosper within the oligotrophic tropical and subtropical oceans (Nelson, Alldredge, McCliment, Amaral-Zettler, \& Carlson, 2011) and are considered among the most productive marinecostal ecosystems (Sorokin, 1993). In them, several species of fishes, mollusks and crustaceans of commercial interest complete their development; therefore, they are economically important for the communities surrounding coral reefs (Birkeland, 1997).

In coral reefs, as in other marine systems, the major energy flux comes from the pelagic-benthic coupling, where zooplankton play the principal role due to diel migration patterns undertaken by many of these organisms 
(Schnack-Schiel \& Isla, 2005). The coral reef zooplankton is represented by complex assemblies from different sources: resident species, demersal migratory species, holozooplankton species from oceanic waters transported onto the reef, and merozooplakton reef species (Heidelberg, Sebens, \& Purcell, 2004). Variations in zooplankton assemblies can reflect environmental alterations more effectively than the environmental variables themselves (Richardson, 2008), due to the sensitivity of organisms to small changes in the environment (Sabatini, 2008).

Isla del Coco is an oceanic island located in the Eastern Tropical Pacific (ETP) about $500 \mathrm{~km}$ from the Costa Rican Pacific coast (Cortés, 2008). The island is surrounded by a complex of several coral reefs (Alvarado et al. 2016), from where two new species of monstrilloid copepods (Suárez-Morales \& MoralesRamírez, 2009) and a new species of pontellid copepod (Esquivel-Garrote, Suárez-Morales \& Morales-Ramírez, 2015) were described recently. However, community structure and distribution of zooplankton in this system remains unknown.

The first attempt to describe the zooplankton community in Isla del Coco was carried out by Morales-Ramirez (2008), who recognized 11 taxonomic groups and 136 species. Other works have focused on specific organisms such as holoplanktonic polychaetes (JiménezCueto, Suárez-Morales, \& Morales-Ramírez, 2012), hyperiid amphipods (Gasca \& MoralesRamírez, 2012), parasitic copepods (SuárezMorales \& Gasca, 2012), appendicularians and chaetognaths (Castellanos, Hernández, Morales-Ramírez, \& Corrales, 2012).

Several studies have described the zooplankton composition and diversity in oceanic islands (Mujica, 1993, 2004, 2006a, 2006b; Melo et al., 2014). However, the information on the coral reef zooplankton in these areas is limited. Zooplankton is a major link in the food webs of coral reefs (Alldrege \& King, 2009) and a key source for allochthonous nutrients for corals (Yahel, Yahel, \& Genin, 2005). The complex zooplankton diversity provides reef ecosystems with substantial nutrient inputs for coral reef fishes, corals and other predators (Heidelberg, O'Neil, Bythell, \& Sebens, 2010). The diel migration patterns of the coral reef zooplankton increase both the biomass and abundance at night, thus becoming an important energy source for plankton feeders like corals (Nakajima, Yoshida, Othman, \& Toda, 2008; Nakajima, Yoshida, Othman, \& Toda, 2009; Heidelberg et al., 2010). Zooplankton provide inorganic nutrients and vitamins which cannot be obtained by the corals through zooxanthellae photosynthesis (Sebens, 1987).

Given the role of zooplankton in coral reef food webs and their susceptibility to small changes in environmental variables, this study aims to provide data on the composition, abundance and biomass of meso- and macrozooplankton in three coral reef systems of Isla del Coco. Based on a statistical analysis we evaluated changes in community structure related to fluctuations in temperature, salinity and dissolved oxygen.

\section{MATERIALS AND METHODS}

Study site: Isla del Coco is an oceanic island located $500 \mathrm{~km}$ southwest from the Pacific coast of Costa Rica, in the Eastern Tropical Pacific (ETP) $\left(5^{\circ} 32^{\prime} \mathrm{N}-87^{\circ} 04^{\prime} \mathrm{W}\right)$. It has $24 \mathrm{~km}^{2}$ of land and $1997 \mathrm{~km}^{2}$ of marine surface. In 1978 it was declared a National Park and UNESCO deemed it as a Human Heritage site in 1997 (Cortés, 2008). The island is influenced by the North Equatorial Countercurrent (NECC), with a seasonal variation in its intensity (Lizano, 2008). The westeast flow carries water and plankton from the central Pacific Ocean to the American coast; thus, Isla del Coco is primarily affected by the NECC and therefore it is the first point for species establishment and distribution in the ETP (Cortés, 2008).

Sampling: Zooplankton samples were collected in March 2009, April 2010, July 2011 and March 2012, in three bays, Wafer, Weston and Chatham, along the northern coast of 
the island (Fig. 1). Porites lobata is the most abundant coral in Isla del Coco; the bottom in Weston Bay is covered mainly by turf and Chatham Bay is the reef with the highest coverage of sand (Alvarado et al. 2016).

Samples were collected for two or three days during the morning, noon and sunset whenever possible from horizontal trawls above the coral reefs, using conical zooplankton nets (mouth diameter $0.49 \mathrm{~m}, 2 \mathrm{~m}$ long, mesh sizes 200 and $500 \mu \mathrm{m}$ ) with a plastic cup. Trawling lasted three minutes for the $200 \mu \mathrm{m}$ net, and five minutes for the $500 \mu \mathrm{m}$, at approximately $1.5 \mathrm{~km} \mathrm{~h}^{-1}$. Hauls were performed making a circle trying to cover the greatest possible area of the coral reef. Before zooplankton sampling, data on water temperature and dissolved oxygen were taken with a multiparameter sonde and salinity was measured with a refractometer. The variables were measured on both the surface and the bottom.

Samples were fixed in $4 \%$ formaldehyde/ sea water solution.

Quantitative and qualitative analysis: Once in the laboratories of CIMAR-UCR, the original samples were fractioned to $1 / 2,1 / 4$ and $1 / 8$ subsamples, depending on sample concentration, using a Folsom splitter (McEven, Johnson \& Folsom, 1954). The remaining fraction used for quantitative analysis and identification was preserved in $70 \%$ ethanol. A minimum of 400 organisms were counted from aliquots taken from the fraction, and emphasis was given to copepod species identification. The volume of water filtered by the net was obtained using the formula $\mathrm{S}=\mathrm{V} / \mathrm{t}$, where $\mathrm{S}$ is the distance, $\mathrm{V}$ is velocity and $\mathrm{t}$ is time; $\mathrm{Vol}=\mathrm{AS}$, where A is the net mouth area. Filtered volumes of $17.45 \mathrm{~m}^{3}$ and $29.08 \mathrm{~m}^{3}$ were obtained from the 200 and $500 \mu \mathrm{m}$ nets, respectively. Abundance was expressed as individuals $\mathrm{m}^{-3}$, and values are given by mean followed by standard deviation.

Zooplankton biomass calculation: Following Boltovskoy (1981) dry weight biomass (DW) was calculated, using a fraction of the original sample obtained with a Folsom splitter. The fraction was filtered using $\mathrm{GF} / \mathrm{C}$ preweighed filters. The filters with the sample were dried at $60^{\circ} \mathrm{C}$ for 24 hours, and weighed in an analytical balance \pm 0.0001 . Biomass is expressed as $\mathrm{mg} \mathrm{DW} \mathrm{m}^{-3}$.

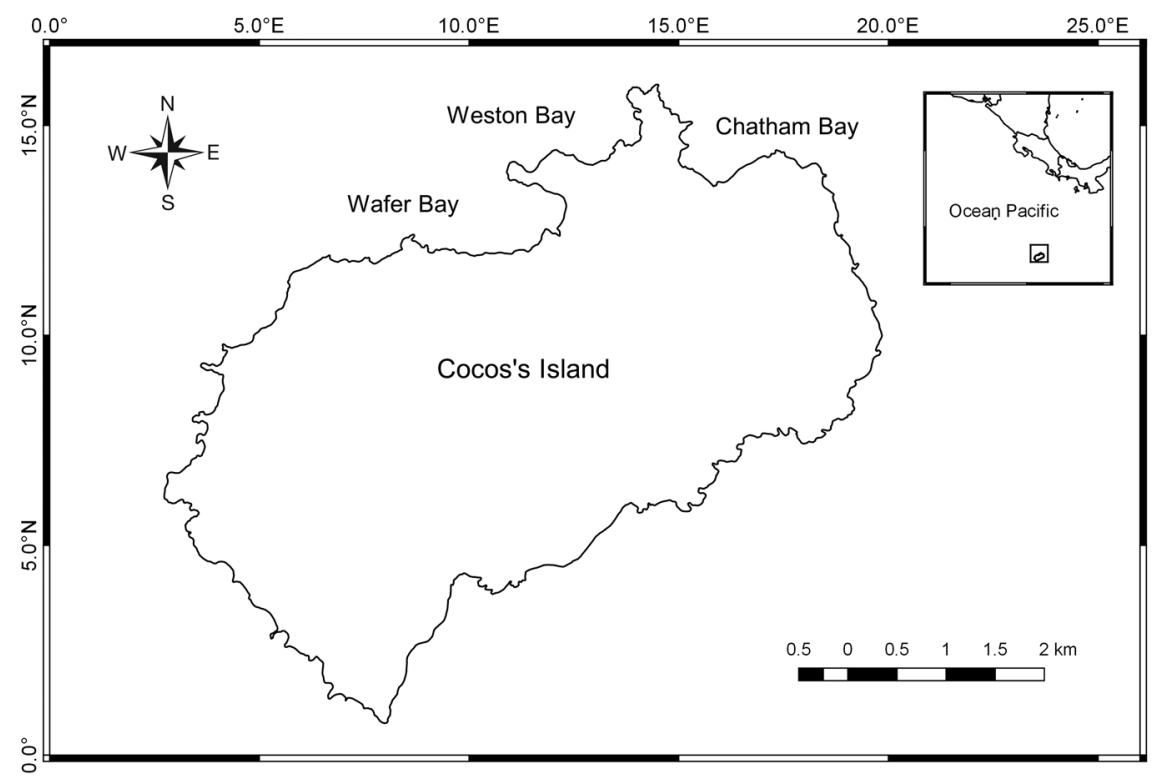

Fig. 1. Locations of zooplankton samplings over coral reefs in three bays at Isla del Coco National Park (2009-2012). 
Statistical analysis: In order to perform the statistical analyses, DW biomass and numerical abundance were standardized through $\log (\mathrm{x}+1)$. When physical and chemical data were used together they were transformed through mean and standard deviation. Normality of the data was tested using the Shapiro-Wilk test and homoscedasticity was tested using the Bartlett test.

Similarities of the zooplankton community composition among years and sample sites were tested by ANOSIM in Primer 6 software (Clarke \& Gorley, 2006), using BrayCurtis distance. To test similarities among each sample site according to community structure, we performed a cluster analysis using a BrayCurtis distance (Clarke \& Gorley, 2006). A Mantel test was done to determine the influence of physical and chemical variables on the zooplankton community structure. If such a relationship was confirmed, a Locally Weighted Scatterplot smoothing (LOESS smoothing) using PAST software (Hammer, Harper \& Ryan, 2001) was performed to visualize the changes in similarity of the community according to variation in environmental variables; euclidean distance was used for physical and chemical data and Bray Curtis distance for biological data. The relationship between abundance and DW biomass in sample sites through time was tested with ANCOVA using the PAST software. An ANOVA without replicas (Quinn and Keough, 2003) in R software (R Development Core Team, 2013) was performed to test if DW biomass and zooplankton abundance show significant differences through time.

\section{RESULTS}

Physical and chemical variables: Water temperature, salinity and dissolved oxygen showed typical values for tropical Pacific waters during the four years (2009-2012) of this study. Temperatures varied from 29 to $30^{\circ} \mathrm{C}$ and were highest in 2012 ; salinity values varied from 31 to 33 psu and the highest value was registered in 2011; dissolved oxygen ranged from 4.4 to $6.3 \mathrm{mg} / \mathrm{l}$ and the highest values were recorded in 2012 (Table 1).

Community composition: In total, 21141 organisms were counted and analyzed, 10752 for macrozooplankton and 10389 for mesozooplankton. For macrozooplankton 24 taxonomic groups and 112 taxa were identified. Copepods were the most abundant taxon in 2009 and 2012 , representing $59 \%$ and $57 \%$ of total abundance; however, in 2010 other groups such as chaetognaths and appendicularians were sampled in higher numbers, and the proportion of copepods decreased to 44\%. In 2011 the

TABLE 1

Values of physical and chemical features during zooplankton sampling in three bays at Isla del Coco National Park, Costa Rica (2009-2012)

\begin{tabular}{lcccc}
\multicolumn{1}{c}{ Site } & Year & Salinity & Temperature $\left({ }^{\circ} \mathrm{C}\right)$ & Dissolved oxygen $(\mathrm{mg} / \mathrm{L})$ \\
Wafer & 2009 & 32,5 & 29,5 & 6,30 \\
& 2010 & 31,0 & 28,9 & 5,50 \\
& 2011 & 31,0 & 28,2 & 6,60 \\
\multirow{3}{*}{ Weston } & 2012 & 30,0 & 29,3 & 5,17 \\
& 2009 & 31,0 & 29,5 & 4,30 \\
& 2010 & 31,0 & 29,3 & 3,90 \\
\multirow{3}{*}{ Chatham } & 32,5 & 27,7 & 4,42 \\
& 2011 & 33,0 & 27,8 & 4,53 \\
& 2012 & 33,0 & 27,8 & 4,77 \\
& 2009 & 32,0 & 30,1 & 6,27 \\
\end{tabular}


abundance of chaetognaths (36\%) exceeded that of copepods (35\%). Ichthyoplankton had relatively high abundance through time, $13 \%$ in 2010 and $8 \%$ in 2011. Mysids increased from $0 \%$ in 2009 to $11 \%$ in 2012 (Table 2).

A total of 48 copepods species were identified, Sapphirinidae being the family with the highest number of species (8 spp.). Sapphirina was the most diverse genus (6 spp.). In other families, such as Corycaeidae and Calanidae, four species were identified. Undinula vulgaris was the most common species during the four years with an average of $52.2 \pm 40.2$ ind $\mathrm{m}^{-3}(4.47 \%)$.

In the mesozooplankton samples 19 taxonomic groups and 81 taxa were identified. Copepods were the most abundant taxon throughout the years of the study, accounting for $69 \%$ in 2010 to $87 \%$ in 2011 . The second most abundant taxa included Appendicularia in $2009(7 \%)$ and $2010(13 \%)$, Chaetognatha in $2011(5 \%)$ and Mollusca in $2012(12 \%)$ (see Table 2). A total of 39 copepod species were identified, Corycaeidae having the highest number of species (two genera, $6 \mathrm{spp}$.); Calanidae and Candacidae were represented by four species each. Paracalanus aculeatus was the species with the highest abundance during the four years with an average of 1063.6 \pm 779.9 ind $\mathrm{m}^{-3}(4.86 \%)$.

Zooplankton temporal variation: The zooplankton community assemblies for macrozooplankton and mesoozooplankton did not show differences between years (ANOSIM, $\mathrm{R}=23.8 \%, \mathrm{p}=0.187$ ) (ANOSIM， $\mathrm{R}=8.60 \%$, $\mathrm{p}=0.335$ ) or bays (ANOSIM, $\mathrm{R}=0.00 \%$, $p=0.455), \quad($ ANOSIM, $\mathrm{R}=8.30 \%, p=0.663)$,

TABLE 2

Percentage of abundance for each zooplankton group per year, for macro- and mesozooplankton at Isla del Coco National Park (2009-2012)

\begin{tabular}{|c|c|c|c|c|c|c|c|c|}
\hline \multirow{2}{*}{$\begin{array}{l}\text { Year } \\
\text { Taxa }\end{array}$} & \multicolumn{2}{|c|}{2009} & \multicolumn{2}{|c|}{2010} & \multicolumn{2}{|c|}{2011} & \multicolumn{2}{|c|}{2012} \\
\hline & Macro & Meso & Macro & Meso & Macro & Meso & Macro & Meso \\
\hline Medusae & 0,04 & 0,06 & 0,07 & 0,03 & 0,28 & 0,00 & 0,00 & 0,00 \\
\hline Siphonophora & 4,25 & 0,24 & 5,42 & 0,20 & 2,37 & 0,12 & 0,97 & 0,33 \\
\hline Polychaeta & 0,04 & 0,00 & 0,18 & 0,32 & 0,28 & 0,28 & 0,06 & 0,08 \\
\hline Bivalvia & 0,17 & 0,73 & 0,36 & 5,68 & 0,00 & 0,04 & 0,00 & 1,42 \\
\hline Pterotracheoida & 0,33 & 0,00 & 0,18 & 0,03 & 1,35 & 0,37 & 0,73 & 2,34 \\
\hline Pteropoda & 0,99 & 2,45 & 3,03 & 4,44 & 2,19 & 1,18 & 1,52 & 8,20 \\
\hline Cephalopada & 0,04 & 0,00 & 0,00 & 0,00 & 0,00 & 0,00 & 0,00 & 0,00 \\
\hline Cladocera & 2,06 & 0,24 & 0,14 & 0,06 & 0,00 & 0,00 & 0,03 & 0,08 \\
\hline Ostracoda & 0,00 & 0,06 & 0,04 & 0,12 & 0,05 & 0,00 & 0,09 & 0,17 \\
\hline Copepoda & 58,91 & 82,91 & 43,61 & 69,67 & 35,43 & 87,14 & 57,18 & 72,13 \\
\hline Nauplio & 0,08 & 0,58 & 0,04 & 0,81 & 0,09 & 1,71 & 0,12 & 3,01 \\
\hline Cirripedia & 0,00 & 0,00 & 0,00 & 0,00 & 0,09 & 0,00 & 0,03 & 0,08 \\
\hline Stomatopoda & 0,04 & 0,00 & 0,07 & 0,00 & 0,14 & 0,04 & 0,00 & 0,00 \\
\hline Myscidacea & 0,00 & 0,00 & 0,00 & 0,00 & 2,61 & 1,42 & 10,65 & 0,33 \\
\hline Amphipoda & 0,83 & 0,06 & 0,32 & 0,12 & 0,79 & 0,16 & 0,88 & 0,00 \\
\hline Isopoda & 0,00 & 0,00 & 0,00 & 0,03 & 0,00 & 0,00 & 0,00 & 0,00 \\
\hline Euphausiacea & 5,07 & 0,95 & 4,01 & 0,69 & 1,72 & 0,08 & 0,47 & 0,00 \\
\hline Decapoda & 4,17 & 0,52 & 3,83 & 0,26 & 4,56 & 0,33 & 6,07 & 2,85 \\
\hline Chaetognatha & 9,20 & 1,71 & 11,88 & 3,32 & 35,61 & 5,33 & 7,95 & 1,59 \\
\hline Larvacea & 1,65 & 7,07 & 13,94 & 13,49 & 2,89 & 1,22 & 1,41 & 5,27 \\
\hline Salpida & 0,95 & 0,00 & 0,07 & 0,00 & 0,28 & 0,00 & 0,18 & 0,00 \\
\hline Doliolida & 0,50 & 0,15 & 0,00 & 0,00 & 1,58 & 0,33 & 0,56 & 0,00 \\
\hline Fish egg & 8,70 & 0,49 & 9,31 & 0,14 & 7,31 & 0,24 & 10,47 & 1,59 \\
\hline Fish larvae & 1,98 & 1,75 & 3,50 & 0,61 & 0,37 & 0,00 & 0,65 & 0,50 \\
\hline
\end{tabular}


respectively. However, variations in surface water temperature, salinity and dissolved oxygen caused unequal abundances (ind $\mathrm{m}^{-3}$ ) between years resulting in a less similar community structure of macrozooplankton $(\mathrm{r}=0.34, p=0.004)$ (Fig. 2A). The same changes were registered for mesozooplankton $(\mathrm{r}=0.35, \mathrm{p}=0.0040)$ (Fig. 2B). The taxa that most contributed to those changes were: Mysida $2.55 \%$, Canthocalanus pauper $2.51 \%$, copepodites $2.16 \%$, Subeucalanus $2.12 \%$ in macrozooplankton, and Clausocalanus copepodite $2.58 \%$, Limacina spp. $2.28 \%$, and Mysida $2.16 \%$ in mesozooplankton samples.

Abundance and biomass: Macrozooplankton abundance reached the highest values in 2012 with $2090.79 \pm 750.97$ ind $\mathrm{m}^{-3}$ and the lowest in 2010 with $368.41 \pm 750.97$ ind $\mathrm{m}^{-3}$. Among bays, the highest mean abundance was at Chatham bay in 2012 with $3302.03 \pm 1290.37$ ind $\mathrm{m}^{-3}$ and the lowest was found at Wafer bay in 2011 with $190.33 \pm 797.72$ ind $\mathrm{m}^{-3}$ (Fig. 3A). There were no significant differences in abundance during different sampling years (ANOVA, $\mathrm{F}=1.26$, d.f. $=7, \mathrm{p}=0.368$ ) or between sample sites (ANOVA, $\mathrm{F}=0.14$, d.f. $=7, p=0.874)$. The highest mean biomass was observed in 2012 with $9.6 \pm 3.8 \mathrm{mg}$ DW $\mathrm{m}^{-3}$, and the lowest occurred in $2010(1.8 \pm 3.8$ $\mathrm{mg} \mathrm{DW} \mathrm{m}^{-3}$ ). Among bays, the highest DW

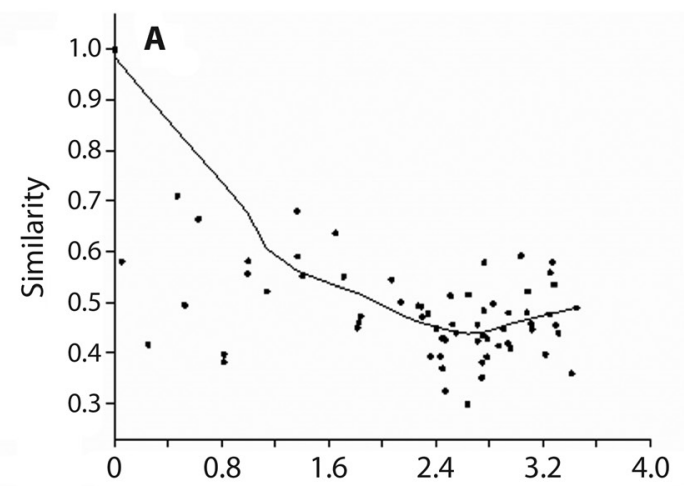

biomass was observed in Chatham bay in 2012 $\left(16.9 \pm 4.3 \mathrm{mg} \mathrm{DW} \mathrm{m}^{-3}\right)$ whereas the lowest values were recorded in Wafer bay (Fig. 3B). There were no significant differences in biomass between years (ANOVA, $\mathrm{F}=0.114$, d. $\mathrm{f}=7$, $\mathrm{p}=0.949$ ) or sample sites (ANOVA, $\mathrm{F}=0.0596$, d.f $=7, p=0.943$ ).

The highest mean abundance for mesozooplankton was recorded in 2011 with $26302.06 \pm 9123.21$ ind $\mathrm{m}^{-3}$ and the lowest in 2012 with $7137.59 \pm 9123.21$ ind $\mathrm{m}^{-3}$. Among bays, Chatham had the highest mean abundance, reaching $42781.30 \pm 15975.80$ ind $\mathrm{m}^{-3}$, and the lowest was found in 2012 at Weston bay with $3666.97 \pm 3007.16$ ind $\mathrm{m}^{-3}$ (Fig 3C). Zooplankton abundance showed significant differences between sample years (ANOVA, $\mathrm{F}=33.79$, d.f. $=7, p=0.001)$ and between bays (ANOVA, $\mathrm{F}=5.78$, d.f. $=7, p=0.040$ ). Zooplankton showed its highest DW biomass mean value in $2009\left(28.8 \pm 21.7 \mathrm{mg} \mathrm{DW} \mathrm{m}^{-3}\right)$; the lowest was in $2012\left(8.9 \pm 21.7 \mathrm{mg} \mathrm{DW} \mathrm{m}^{3}\right)$. DW zooplankton biomass was highest in Chatham bay in $2011\left(50.1 \pm 17.3 \mathrm{mg} \mathrm{DW} \mathrm{m}^{-3}\right)$, whereas the lowest value was observed in Weston bay in $2012\left(5.7 \pm 4.4 \mathrm{mg} \mathrm{DW} \mathrm{m}^{-3}\right)$; in $2010 \mathrm{DW}$ biomass values were similar in the three bays (Fig. 3D). Biomass showed significant differences between years (ANOVA, $\mathrm{F}=15.44$, d.f $=7, p=0.00315)$, and between sample sites (ANOVA, $F=6.18$, d. $f=7, p=0.0348$ ).

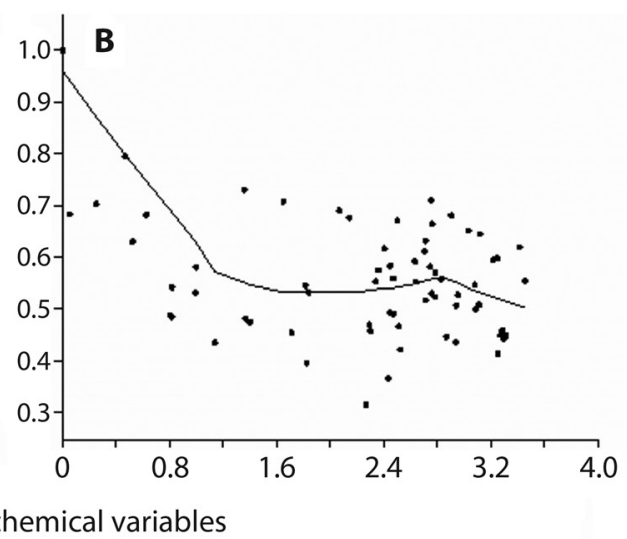

Fig. 2. Relationship between changes in environmental variables and similarity of zooplankton community, (A) for $500 \mu \mathrm{m}$ net mesh and (B) for $200 \mu \mathrm{m}$ net mesh, Isla del Coco National Park (2009-2012). 

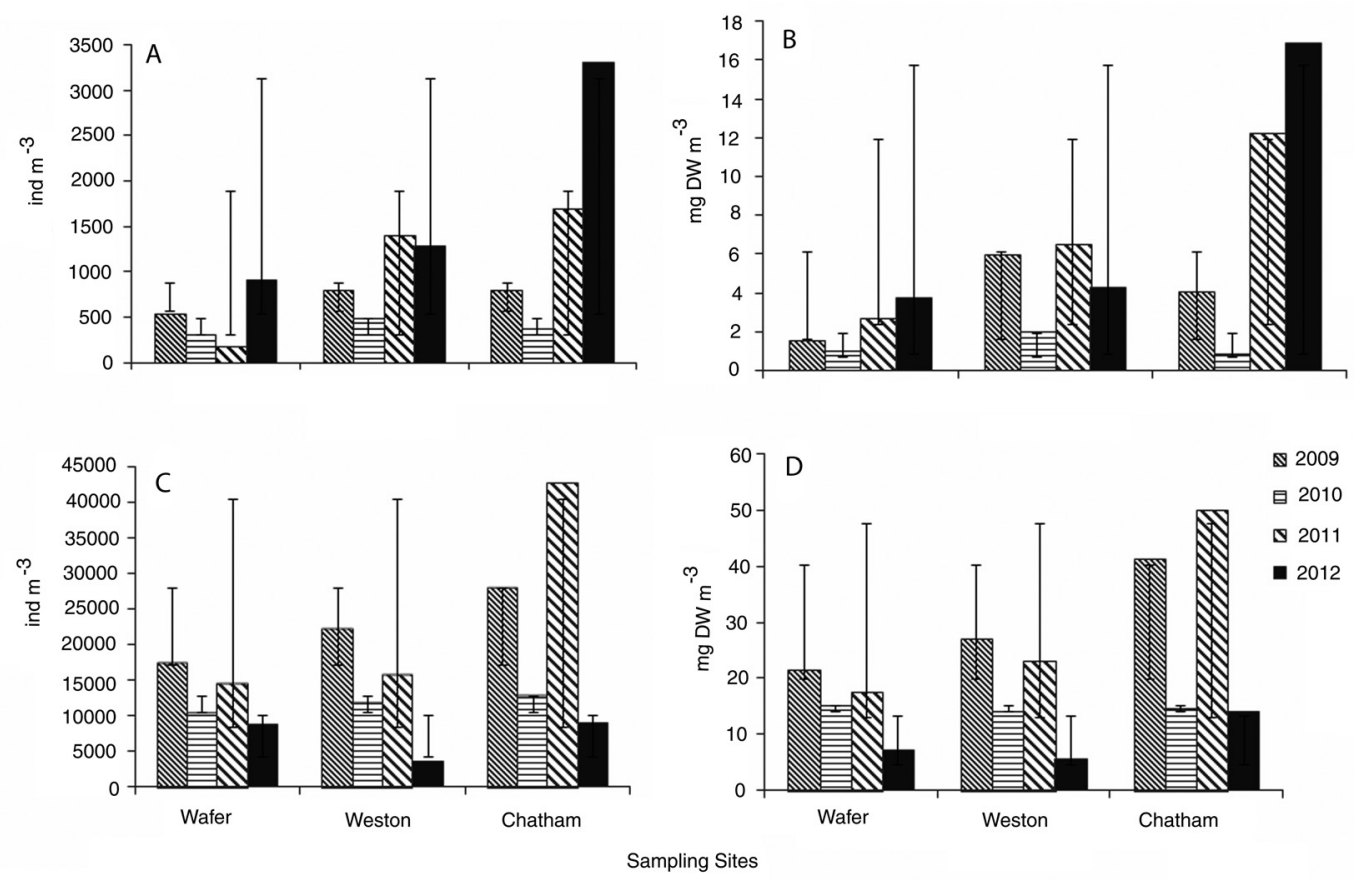

Fig. 3. (A) Average density of organisms and (B) average biomass per year and sample location for zooplankton sampled with $500 \mu \mathrm{m}$ net mesh. (C) Average density of organism and (D) average biomass per year and sample location for zooplankton sampled with $200 \mu \mathrm{m}$ net mesh. Isla del Coco National Park, 2009-2012.

Macro and mesozooplankton biomass and abundance were positively correlated among bays and years (ANCOVA, $\mathrm{F}=0.33, p=0.729$ ), (ANCOVA, $\mathrm{F}=0.15, p=0.880$ ) respectively (Fig. 4).

\section{DISCUSSION}

\section{Zooplankton richness and taxonomic} composition: The Isla del Coco waters are characterized by a typical epipelagic copepod fauna, dominated by calanoid species. Zooplankton density is dominated by mesozooplankton organisms and variations in physical and chemical variables influence the zooplankton community composition in Isla del Coco coral reefs.

The composition of coral reef zooplankton in Isla del Coco is similar to that found it in other oceanic islands. In this study Calanoida showed the highest number of species followed by Poecilostomatoida. These results are similar to those of Melo et al., (2014) where in the Saint Peter and Saint Paul archipelago in the Atlantic Ocean a higher number of calanoid copepod species were found, followed by Cyclopoida, and $U$. vulgaris and $P$. aculeatus were the most common species, followed by the oncaeids and corycaeids. Suarez-Morales \& Gasca (2000), in the Mexican Caribbean, found $U$. vulgaris to be the most representative species in the reef, and this species in particular has been described as indicating the extent of the oceanic influence in the reef environments (Renon, 1993). Copepods belonging to the genera Paracalanus, Oithona and Oncaea were dominant components of the coral reef copepod community in the Redang and Tioman islands, Malaysia (Nakajima et al, 2008, 2009), similar to the results found in our study. The study by Mujica (1993) in Eastern Island show similar results to this study, where copepods had the highest abundance, followed by 
chaetognaths, euphausids and lower abundances of decapod larvae and ichthyoplankton. Our study differs from that of Mujica (1993) in that the latter found a greater number of euphausids, $8.54 \%$ as opposed to 1 to $4 \%$ in our study, and an appendicularian abundances of 2\% in Easter Island versus 5 to $7 \%$ in Isla del Coco.

Some differences can be found between Isla del Coco zooplankton assemblages and continental coral reef systems, where decapod larvae and zoeae constitute important taxa after copepods, as was recorded by Guzmán \& Obando (1988) in Isla del Caño, Costa Rica, and in the Yucatan Península, Mexico (Castellanos Osorio \& Suarez-Morales, 1997). Groups like ichthyoplankton and molluscs show similarities in abundance in both coral reef systems. Comparing Isla del Coco with other insular coral reef systems under oceanic influence, similarities in community composition and abundance are found, copepods, appendicularians and chaetognaths being the three major groups in terms of abundance, as was recorded by Hamner, Colin \& Hamner (2007) in Palau, Nakajima \& Yoshida (2008) in Tioman Island, Malaysia, and Nakajima, Yoshida, Otman \& Toda (2008) in Redang Island, Malaysia.

Differences in community structure of macro- and mesozooplankton were found with respect to variations in physical and chemical variables (water temperature, salinity and dissolved oxygen). Similar results were found in Culebra Bay, Costa Rica, where appendicularians, zoeae, naupli and two copepod species showed a positive correlation with dissolved oxygen, while copepods and ostracods species were correlated with salinity (Bednarski \& Morales-Ramírez, 2004). Geographic and oceanographic conditions in an area could cause saline and thermic variations, not detectable on a large scale but important for some organisms (Suárez-Morales \& Rivera-Arriaga, 1998). Changes in the relative abundance of some taxonomic groups of zooplankton groups reflect local changes in salinity, temperature, light, density, water circulation and other physical and biological factors. This environmental variation on a temporal and spatial scale causees changes in the number, abundance and diversity of zooplankton taxa (Hernández-Trujillo, EsquedaEscárcega, G \& Palomares-García, 2010).

A higher number of macrozooplankton taxa agrees with the results of Tseng, Dahms, Hung, Chen \& Hwang, (2011) in the China Sea, where the highest number of taxa were collected with larger mesh net size $(330 \mu \mathrm{m})$. Although larger mesh net size $(>200 \mu \mathrm{m})$ underestimates the number of relatively small copepod species, their copepodites (e.g. Acartia, Calocalanus, Clausocalanus) and many harpacticoids (Gallienne \& Robinson, 2011), thin mesh net size can cause an underestimation of larger taxa (i.e. copepods of $2 \mathrm{~mm}$ or more) due to the generated current, the filtering efficiency and evasion by larger organisms (Fleminger \& Clutter, 1965; Tseng et al., 2011; Makabe et al., 2012).

A high abundance of larvaceans was recorded in a coral reef system in Malaysia, reaching second place after copepods (Nakajima, Yoshida, Othman \& Toda, 2014). These densities could be linked to an increase in pico and nanoplakton, which in turn might increase the number of Appendicularia (Arevana \& Palma, 2002), but there are no data in situ to support this possibility. However, through satellite data Lizano (2008) reported the influence of a bloom near the Costa Rican coast from January to March in the Isla del Coco, increasing phytoplankton concentrations, a situation that could be favorable to the appendicularians, with an increased abundance in April after the bloom.

The higher densities of Chaetognatha in 2011 could be explained by the availability of prey such as appendicularians and copepods, since chaetognaths feed mainly on appendicularians and copepods (Froneman \& Pakhomov, 1998; Tönneson \& Tiselius, 2005). Flaccisagitta enflata, a common chaetognath species in the Isla del Coco (Morales-Ramírez, 2008), showed a feeding preference for larvaceans and copepods (Lie \& Wong, 2012), suggesting that this feeding behavior could have an impact on the composition of zooplankton communities and influence the abundance of copepods 

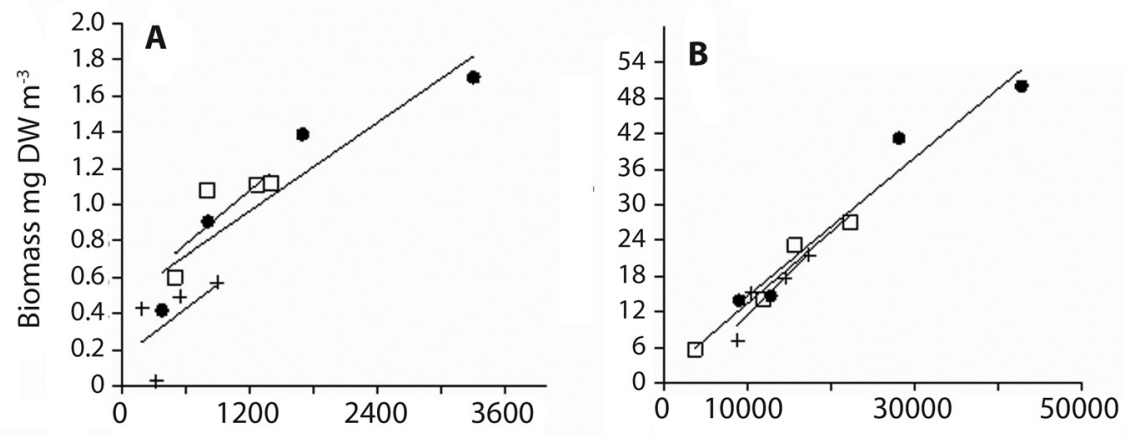

Density ind $\mathrm{m}^{-3}$

Fig. 4. Relationship between density and biomass for $500 \mu \mathrm{m}$ net mesh and (B) for $200 \mu \mathrm{m}$ net mesh. Dots for Chatham Bay, squares for Weston Bay and crosses for Wafer Bay (Isla del Coco National Park), during 2009-2012.

(Froneman, Pakhomov, Perissinotto, \& Meaton, 1998; Giesecke \& González, 2004).

Dry weight biomass: The DW biomass was dominated by the mesozooplankton community, but in 2012 the macrozooplankton community surpassed the mesozooplankton, which could result from a succession of larger over small-bodied organisms. When available food concentrations rise, the biomass of small organisms may increase as a response to phytoplankton production, reflected later in time by an increase in biomass of larger bodied organisms (Suárez-Morales \& Gasca, 1994). In the Sargasso sea a succession of macrozooplankton over mesozooplankton was observed, with increased macrozooplankton biomass through time, suggesting that predation is more important than food availability in controlling the populations of small herbivores (Davis \& Wiebe, 1985). Predation control over small zooplankton herbivores has been documented in coastal regions (Davis, 1984), and it could be an important mechanism in oligotrophic oceanic regions where food supply is low (Hayward \& McGowan, 1979). A positive correlation between zooplankton density and DW biomass was expected and has been reported in others studies, including in the Balearic Sea (Fernández de Puelles et al. 2003). This correlation is more significant in nets with the smallest-sized mesh where density and biomass are higher (Buskey, 1993; Auel \& Hagen, 2002; Fernández de Puelles, Grás \& HernándezLeón, 2003), thus supporting our results, due to small-sized organisms characteristic of oligotrophic waters.

Our results showed that small organisms dominated the DW biomass at Isla del Coco coral reefs, but under certain oceanographic conditions a succession of larger over smallbodied organisms could increase macrozooplankton biomass due to predation of large organisms on small ones.

Another factor that could have affected zooplankton abundance and biomass during the study was the influence of El Niño-Southern Oscillation (ENSO) in 2010 (Sarachik \& Cane, 2010). Changes in biomass, lower abundances and species shifting are some of the implications of ENSO on the zooplankton community (Gómez-Gutierrez, Palomares-García, \& Gendron, 1995; González, Sobarzo, Figueroa, \& Nöthig, 2000). The low abundance of copepods in samples taken with the $500 \mu \mathrm{m}$ mesh net during 2010 and 2011 was due to the large number of Appendicularia and Chaetognatha. Appendicularia increased its abundances in 2010. During the present study, in 2010 both biomass and abundance declined in almost every sample station. Similar results were found by Kozak, Franco-Gordo, Suárez-Morales, and Palomares-García (2014) in the ETP, who recorded a significantly lower abundance of 
copepods during the ENSO period in 1997 1998. The same situation was reported in the Oregon coast during the same ENSO event where, besides the decline in biomass and abundance, there was a shift in copepod species, winter species being replaced by summer species as a consequence of warming waters (Peterson, Keister, \& Feinberg 2002). However, the present study did not find a shift in species composition.

The results of this study show that coral reef zooplankton in Isla del Coco is typical of that of tropical and subtropical insular oceanic and coral reef lagoons under oceanic influence, characterized by high abundances of calanid copepods, chaetognaths and larvaceans. Zooplankton community composition in Isla del Coco did not show differences during the four seasons of sampling, but zooplankton biomass and abundance was apparently affected by season and oceanographic conditions. Additional efforts must be made to learn more about the dynamics of zooplankton in oceanic islands and understand the effect of islands in a world of global change.

Ethical statement: authors declare that they all agree with this publication and made significant contributions; that there is no conflict of interest of any kind; and that we followed all pertinent ethical and legal procedures and requirements. All financial sources are fully and clearly stated in the acknowledgements section. A signed document has been filed in the journal archives.

\section{ACKNOWLEDGMENTS}

We thank Jeffrey Sibaja for help with statistical analysis, Jorge Cortés, Gerardo Umaña, Juan José Alvarado and Jeffrey Sibaja for comments on this work, Marco Corrales-Ugalde for helping with the gelatinous zooplankton identification, Sea Hunter Group and Isla del Coco National Park personnel for help with sampling and to professor Guilherme R. S. Muricy for valuable comments and corrections. This work was supported by the Consejo Nacional de
Rectores (CONARE) through grant 808-B0654, and grant 808-A7-520 from the French GEF and 808-B0-060.

\section{RESUMEN}

Estructura de la comunidad de zooplancton en arrecifes coralinos del Parque Nacional Isla del Coco, sitio Patrimonio de la Humanidad en el Pacífico Tropical Oriental. Introducción: El zooplancton es el principal enlace entre los productores primarios y los siguientes niveles de la cadena trófica, en los arrecifes de coral representa una importante fuente de alimento, en estos ambientes comprende una amplia variedad de especies de diferentes grupos funcionales. Métodos: En el presente trabajo se analiza la estructura de la comunidad del zooplancton asociado a los sistemas arrecifales de la Isla del Coco, sus variaciones interanuales y como las variables físicas y químicas en diferentes épocas influencian la composición de especies. Las muestras se colectaron sobre los parches de arrecife de Bahía Weston, Bahía Wafer y Bahía Chatham en el sector norte de la Isla, en cuatro periodos, en 2009 a 2012, se realizaron arrastres horizontales con redes cilindro cónicas de 200 y $500 \mu \mathrm{m}$ tamaño de poro, durante tres e cinco minutos respectivamente a diferentes horas del día. Resultados: Se identificaron 24 grupos taxonómicos dentro del Macrozooplancton y 22 dentro del Mesozooplancton. Mayores abundancias y biomasas se registraron en el Mesozooplancton. Copépodos, apendicularias e quetognatos fueron los grupos más abundantes, siendo afectadas sus abundancias por las variaciones en las variables físicas y químicas. Conclusiones: La comunidad zooplanctónica de los arrecifes coralinos en la Isla del Coco es semejante a aquellos sistemas arrecifales de zonas oceánicas bajo la influencia de aguas oceánicas, con una fauna conformada principalmente por copépodos, quetognatos y apendicularias y que dependiendo de las características oceanográficas imperantes las abundancias de estos grupos pueden cambiar.

Palabras clave: Isla del Coco; isla oceánica; plancton; variables ambientales; abundancia; diversidad; biomasa.

\section{REFERENCES}

Alvarado, J. J., Beita-Jiménez, A., Mena, S., FernándezGarcía, C., Guzman-Mora, A. G., \& Cortés, J. (2016). Ecosistemas coralinos del Parque Nacional Isla del Coco, Costa Rica: estructura y comparación 19872014. Revista de Biología Tropical, 64(Supplement 1), 153-175.

Aravena, G., \& Palma, S. (2002). Taxonomic identification of appendicularians collected in the epipelagic waters off northern Chile (Tunicata, Appendicularia). Revista Chilena de Historia Natural, 75, 307-325. 
Auel, H., \& Hagen, W. (2002). Mesozooplankton community structure, abundance and biomass in the central Arctic Ocean. Marine Biology, 140(5), 1013-1021.

Bednarski, M., \& Morales-Ramírez, A. (2004). Composition, abundance and distribution of macrozooplankton in Culebra Bay, Gulf of Papagayo, Pacific coast of Costa Rica and its value as bioindicator of pollution. Revista de Biología Tropical, 52, 105-119.

Boltovskoy, D. (1981). Atlas del zooplancton marino del Atlántico Occidental y métodos de trabajo con el zooplancton marino. Buenos Aires, Argentina: Instituto Nacional de Investigación y Desarrollo Pesquero.

Buskey, E. J. (1993). Annual pattern of micro-and mesozooplankton abundance and biomass in a subtropical estuary. Journal of Plankton Research, 15(8), 907-924.

Castellanos, I., Hernández. R. M., Morales-Ramírez, A., \& Corrales, M. (2012). Appendicularians (Urochordata) and chaetognaths (Chaetognatha) of Isla del Coco National Park, Revista de Biología Tropical, 60(Supplement 3), 243-255.

Clarke, K. R., \& Gorley, R. N. (2006). PRIMER v6: User Manual/Tutorial (Plymouth Routines in Multivariate Ecological Research). PRIMER-E, Plymouth.

Cortés, J. (2008). Historia de la investigación marina de la Isla del Coco, Costa Rica. Revista de Biología Tropical, 56(Supplement 2), 1-18.

Davis, C. S. (1984). Predatory control of copepod seasonal cycles on George Bank. Marine Biology, 82, 31-40.

Davis, C. S., \& Wiebe, P. H. (1985). Macrozooplankton biomass in a Warm-Core Gulf Stream Ring: Time series changes in size structure, taxonomic composition and vertical distribution. Journal of Geophysics Research, 90, 8871-8884.

de Puelles, M. F., Grás, D., \& Hernández-León, S. (2003). Annual cycle of zooplankton biomass, abundance and species composition in the neritic area of the Balearic Sea, Western Mediterranean. Marine Ecology, 24(2), 123-139.

Emery, A. R. (1968). Preliminary observations on coral reef plankton 1. Limnology and Oceanography, 13(2), 293-303.

Fleminger, A., \& Clutter, R. I. (1965). Avoidance of Towed Nets by zooplankton. Limnology and Oceanography, 10(1), 96-104.

Froneman, P. W., \& Pakhomov, E. A. (1998). Trophic importance of the chaetognaths Eukrohnia hamata and Sagitta gazellae in the pelagic system of the Prince Edward Islands (Southern Ocean). Polar Biology, 19(4), 242-249.
Froneman, P. W., Pakhomov, E. A., Perissinotto, R., \& Meaton, V. (1998). Feeding and predation impact of two chaetognath species, Eukrohnia hamata and Sagitta gazellae, in the vicinity of Marion Island (southern ocean). Marine Biology, 131(1), 95-101.

Gallienne, C. P., \& Robins, D. B. (2001). Is Oithona the most important copepod in the world's oceans? Journal of Plankton Research, 23, 1421-1432.

Gasca, R., \& Morales-Ramírez, A. (2012). Hyperiid amphipods (Crustacea: Peracarida) of the Parque Nacional Isla del Coco, Costa Rica, Eastern Tropical Pacific. Revista de Biología Tropical, 60(Supplement 3), 223-233.

Giesecke, R., \& González, H. E. (2004). Feeding of Sagitta enflata and vertical distribution of chaetognaths in relation to low oxygen concentrations. Journal of Plankton Research, 26(4), 475-486.

Gómez-Gutiérrez, J., Palomares-García, R., \& Gendron, D. (1995). Community structure of the euphausiid populations along the west coast of Baja California, Mexico, during the weak ENSO 1986-1987. Marine Ecology Progress Series, 120, 41-51.

González, H. E., Sobarzo, M., Figueroa, D., \& Nöthig, E-M. (2000). Composition, biomass and potential grazing impact of the crustacean and pelagic tunicates in the northern Humboldt Current area off Chile: differences between El Niño and non-El Niño years. Marine Ecology Progress Series, 195, 201-220.

Guzmán, H. M., \& Obando, V. L. (1988). Diversidad y abundancia diaria y estacional del zooplancton marino de la Isla del Caño, Costa Rica. Revista de Biología Tropical, 36(1), 139-150.

Hammer, Ø., Harper, D.A.T., \& Ryan, P.D. (2001). PAST: Paleontological statistics software package for education and data analysis. Palaeontologia Electronica, 4(1), 1-9.

Hamner, W. M., Colin, P. L., \& Hamner, P. P. (2007). Export-import dynamics of zooplankton on a coral reef in Palau. Marine Ecology Progress Series, 334, 83-92.

Hayward, T. L., \& McGowan, J. A. (1979). Pattern and structure in an oceanic zooplankton community. American Zoologist, 19(4), 1045-1055.

Heidelberg, K., Sebens, K., \& Purcell, J. (2004). Composition and sources of near reef zooplankton on a Jamaican forereef along with implications for coral feeding. Coral Reefs, 23(2), 263-276.

Heidelberg, K. B., O’Neil, K. L., Bythell, J. C., \& Sebens, K. (2010). Vertical distribution and diel patterns of zooplankton abundance and biomass at Conch Reef, Florida Keys (USA). Journal of Plankton Research, 32(1), 75-91. 
Hernández-Trujillo, S., Esqueda-Escárcega, G., \& Palomares-García, R. (2010). Variabilidad de la abundancia de zooplancton en Bahía Magdalena Baja California Sur, México (1997-2001). Latin american journal of aquatic research, 38(3), 438-446.

Hobson, E. S., \& Chess, J. R. (1978). The Lagoon at Enewetak atoll, Marshall Islands. Fishery Bulletin, $76(1)$.

Jiménez-Cueto, S., Suárez-Morales, E., \& Morales-Ramírez, A. (2012). Algunos poliquetos holoplanctónicos (Annelida: Polychaeta) del Parque Nacional Isla del Coco, Costa Rica, Revista de Biología Tropical, 60(Supplement 3), 207-222.

Kozak, E. R., Franco-Gordo, C., Suárez-Morales, E., \& Palomares-García, R. (2014). Seasonal and interannual variability of the calanoid copepod community structure in shelf waters of the Eastern Tropical Pacific. Marine Ecology Progress Series, 507, 95-110

Lie, A., Tse, P., \& Wong, C. (2012). Diel vertical migration and feeding of three species of chaetognaths (Flaccisagitta enflata, Aidanosagitta delicata and Aidanosagitta neglecta) in two shallow, subtropical bays in Hong Kong. Journal of Plankton Research, 34(8), 670-684.

Lizano, O. (2008). Dinámica de aguas alrededor de la Isla del Coco, Costa Rica. Revista de Biología Tropical, 56(Supplement 2), 31-48.

Makabe, R., Nimura, A., \& Fukuchi, M. (2012). Comparison of mesh size effects on mesozooplankton collection efficiency in the Southern Ocean. Journal of Plankton Research, 34, 432-436.

McEwen, G. F., Johnson, M. W., \& Folsom, T. R. (1954). A statistical analysis of the performance of the Folsom Plankton Sample Splitter, based upon the observations. Archives for Meteorology, Geophysics and Climatology, 7, 502-527.

Melo, P., Silva, T., Neumann-Leitão, S., Schwamborn, R., Gusmão, L., \& Neto, F. (2010). Demersal zooplankton communities from tropical habitats in the southwestern Atlantic, Marine Biology Research, 6(6), 530-541.

Morales, E. S., \& Arriaga, E. R. (1998). Zooplacton e hidrodinámica en zonas litorales y arrecifales de Quintana Roo, México. Hidrobiológica, 8(1), 19-32.

Morales-Ramírez, A. (2008). Caracterización cualitativa del zooplancton del Área de Conservación Marina Isla del Coco (ACMIC), Océano Pacífico de Costa Rica. Revista de Biología Tropical, 56(Supplement 2), 159-169.

Mujica, A. (1993). Zooplancton de las aguas circundantes a la Isla de Pascua $\left(27^{\circ} 08^{\prime} \mathrm{S}-109^{\circ} 26^{\prime} \mathrm{W}\right)$, Revista Ciencia Tecnología del Mar, 16, 55-61.
Mujica, A. (2006a). Larvas de crustáceos decápodos y crustáceos holoplanctónicos en torno a la Isla de Pascua. Revista Ciencia Tecnología del Mar, 29(1),123-135.

Mujica, A. (2006b). Larvas de crustáceos decápodos del archipiélago Juan Fernández (33 $\left.40^{\prime} \mathrm{S}-78^{\circ} 50^{\prime} \mathrm{W}\right)$ e islas Desventuradas $\left(26^{\circ} 20^{\prime} \mathrm{S}-80^{\circ} 05^{\prime} \mathrm{W}\right)$. Revista Ciencia Tecnología del Mar, 29(1), 137-152.

Nakajima, R., Yoshida, T., Othman, B., \& Toda, T. (2008). Diel variation in abundance, biomass and size composition of zooplankton community over a coral-reef in Redang Island, Malaysia. Plankton and Benthos Research, 3(4), 216-226.

Nakajima, R., Yoshida, T., Othman, B., \& Toda, T. (2009). Diel variation of zooplankton in the tropical coralreef water of Tioman Island, Malaysia. Aquatic Ecology, 43(4), 965-975.

Nakajima, R., Yoshida, T., Othman, B., \& Toda, T. (2014). Biomass and estimated production rates of metazoan zooplankton community in a tropical coral reef of Malaysia. Marine Ecology, 35(1), 112-131.

Nelson, C., Alldredge, A., McCliment, E., Amaral-Zettler, L., \& Carlson, C. (2011). Depleted dissolved organic carbon and distinct bacterial communities in the water column of a rapid flushing coral reef ecosystem. The International Society of Microbial Ecology Journal, 5, 1374-1387.

Osório, I. A. C., \& Morales, E. S. (1997). Observaciones sobre el zooplancton de la zona arrecifal de Mahahual, Quintana Roo (Mar Caribe Mexicano). Anales del Instituto de Biología. Serie Zoología, 68(2), 237-252.

Peterson, W. T., Keister, J. E., \& Feinberg, L. R. (2002). The effects of the 1997-99 El Niño/La Niña events on hydrography and zooplankton off the central Oregon coast. Progress in Oceanography, 54(1-4), 381-398.

Quinn, G. P., \& Keough, M. J. (2003). Experimental design and data analysis for biologists. Cambridge, United Kingdom: Cambridge University Press.

R Core Team. (2013). R: A language and environment for statistical computing. Vienna: R Foundation for Statistical Computing. URL http://www.R-project.org/

Renon, J. R. (1993). Répartition du copépode planctonique Undinula vulgaris (Dana) dans trois types de milieux coralliens. Annales de l'Institut océanographique, 69(2), 239-247.

Richardson, A. J. (2008). In hot water: zooplankton and climate change. International Council of the Exploration of the Sea Journal of Marine Science, 65, 279-295.

Sabatini, M. (2008). El ecosistema de la plataforma patagónica austral, marzo-abril 2000. Composición, 
abundancia y distribución del zooplancton. Revista de Investinvestigación y Desarrollo Pesquero, 19, 5-21.

Sarachik, E. S., \& Cane, M. A. (2010). The El Ninosouthern oscillation phenomenon. Cambridge, United Kingdom: Cambridge University Press.

Schnack-Schiel, S., \& Isla, E. (2005). The role of zooplankton in the pelagic-benthic coupling of the Southern Ocean. Scientia Marina, 69, 39-55.

Sebens, K. P. (1987). Coelenterata. In F. J. Vernberg, \& T. J. Pandian (Eds.), Animal energetics (pp. 55-120). New York: Academic Press.

Suárez-Morales, E., \& Gasca, R. (1994). Zooplankton Biomass Fluctuations in a Mexican Caribbean Bay (Bahía de la Ascensión) during a Year Cycle. Caribbean Journal of Science, 30, 116-123.

Suárez-Morales, E., \& Gasca, R. (2000). The planktonic copepod community at Mahahual reef, Western Caribbean. Bulletin of Marine Science, 66(1), 255-267.
Suárez-Morales, E., \& Gasca, R. (2012). A new Lepeophtheirus (Copepoda: Siphonostomatoida: Caligidae) from Isla del Coco National Park, Costa Rica, Eastern Tropical Pacific, Revista de Biología Tropical, 60(3), 235-242.

Suárez-Morales, E., \& Morales-Ramírez, A. (2009). New species of Monstrilloida (Crustacea: Copepoda) from the Eastern Tropical Pacific. Journal of Natural History, 43, 1257-1271.

Tönnesson, K., \& Tiselius, P. (2005). Diet of the chaetognaths Sagitta setosa and $S$. elegans in relation to prey abundance and vertical distribution. Marine Ecology Progress Series, 289, 177-190.

Tseng, L. C., Dahms, H. U., Hung, J. J., Chen, Q. C., \& Hwang, J. S. (2011). Can different mesh sizes affect the results of copepod community studies?. Journal of Experimental Marine Biology and Ecology, 398(12), 47-55

Yahel, R., Yahel, G., \& Genin, A. (2005). Near- bottom depletion of zooplankton over coral reefs: I: diurnal dynamics and size distribution. Coral Reefs, 24(1), 75-85. 